\title{
Beta Amyloid-Induced Depression of Hippocampal Long-Term Potentiation Is Mediated through the Amylin Receptor
}

\author{
Ryoichi Kimura, ${ }^{1,2}$ David MacTavish, ${ }^{2}$ Jing Yang, ${ }^{4}$ David Westaway, ${ }^{2,3,4}$ and Jack H. Jhamandas ${ }^{2}$ \\ ${ }^{1}$ Department of Medicine, Hyogo College of Medicine, Nishinomiya, 663-8501, Hyogo, Japan, and 2Department of Medicine (Neurology) and Centre for \\ Neuroscience, and ${ }^{3}$ Department of Biochemistry, ${ }^{4}$ Centre for Prions and Protein Folding Diseases, University of Alberta, Edmonton, Alberta, Canada T6G 2S2
}

\begin{abstract}
Alzheimer's disease $(\mathrm{AD})$ is characterized by accumulation of amyloid- $\beta$ peptide $(\mathrm{A} \beta)$ in the brain regions that subserve memory and cognition. The amylin receptor is a potential target receptor for expression of the deleterious actions of soluble oligomeric $\mathrm{A} \beta$ species. We investigated whether the amylin receptor antagonist, AC253, neutralizes the depressant effects of A $\beta_{1-42}$ and human amylin on hippocampal long-term potentiation (LTP). Furthermore, we examined whether depressed levels of LTP observed in transgenic mice, which overexpress amyloid precursor protein (TgCRND8), could be restored with AC253. In mouse hippocampal brain slices, field EPSPs were recorded from the stratum radiatum layer of the CA1 area (cornu ammonis 1 region of the hippocampus) in response to electrical stimulation of Schaeffer collateral afferents. LTP was induced by 3-theta burst stimulation protocols. A $\beta_{1-42}(50 \mathrm{nM})$ and human amylin ( $50 \mathrm{nM})$, but not $\mathrm{A} \beta_{42-1}(50 \mathrm{nM})$, depressed LTP evoked using both stimulation protocols. Preapplication of AC253 (250 nM) blocked A $\beta$ and human amylin-induced reduction of LTP without affecting baseline transmission or LTP on its own. In contrast to wild-type controls, where robust LTP is observed, 6- to 12-month-old TgCRND8 mice show blunted LTP that is significantly enhanced by application of AC253. Our data demonstrate that the effects of $\mathrm{A} \beta_{1-42}$ and human amylin on LTP are expressed via the amylin receptor, and moreover, blockade of this receptor increases LTP in transgenic mice that show increased brain amyloid burden. Amylin receptor antagonists could serve as potentially useful therapeutic agents in $\mathrm{AD}$.
\end{abstract}

\section{Introduction}

Alzheimer's disease (AD) represents one of the most serious health and societal burdens of our time, yet at present, there is no proven treatment beyond symptomatic therapies. The accumulation and deposition of amyloid- $\beta$ peptide $(A \beta)$, a $39-43$ aa peptide, in brain areas critical for cognition and memory is an important factor in the pathogenesis of AD (Selkoe, 2008). Large, insoluble deposits of $\mathrm{A} \beta$ in plaque form coexist with small, diffusible soluble oligomers of the peptide in cortical and limbic regions of $\mathrm{AD}$ brains. Soluble $\mathrm{A} \beta$ oligomers, composed of dimers, trimers, tetramers and higher order assemblies, consistently inhibit hippocampal long-term potentiation (LTP), a surrogate in vitro cellular model for memory and learning (Walsh et al., 2002). Furthermore, naturally secreted $\mathrm{A} \beta$ oligomers potently inhibit hippocampal LTP in vivo, which is reversible by passive infusions of

\footnotetext{
Received June 26, 2012; revised 0ct. 8, 2012; accepted 0ct. 9, 2012.

Author contributions: R.K. and J.H.J. designed research; R.K. and D.M. performed research; J.Y., D.W., and J.H.J. contributed unpublished reagents/analytic tools; R.K., D.M., and J.H.J. analyzed data; R.K., D.W., and J.H.J. wrote the paper.

This research was supported by funding from the Canadian Institutes of Health Research (MOP 93601 to J.H.J.) and the Alberta Prion Research Institute (APRI 200600070 to D.W.).

The authors declare no competing financial interests.

Correspondence should be addressed to Dr. Jack H. Jhamandas, 530 Heritage Medical Research Centre, Department of Medicine (Neurology), University of Alberta, Edmonton, AB, Canada T6G 2S2. E-mail: jack. jhamandas@ualberta.ca.

DOI:10.1523/JNEUROSCI.3028-12.2012

Copyright $\odot 2012$ the authors $\quad 0270-6474 / 12 / 3217401-06 \$ 15.00 / 0$
}

either $\mathrm{A} \beta$ antibodies or administration of an active $\mathrm{A} \beta$ vaccine (Klyubin et al., 2005). Tg2576 mice, which overexpress mutant amyloid precursor protein (APP), when treated with a $\gamma$-secretase inhibitor to reduce $A \beta$ levels, demonstrate a profound restoration of impaired LTP (Townsend et al., 2010). Thus, understanding the mechanisms whereby soluble $\mathrm{A} \beta$ oligomers can disrupt synaptic function is of great interest in preventing $\mathrm{AD}$ progression. Multiple candidate receptors, located pre- or postsynaptically, have been implicated in mediating $\mathrm{A} \beta$ disruption of synaptic processes and are potential targets for developing anti-A $\beta$ therapies (Huang and Mucke, 2012).

Of these receptors, we have identified the amylin receptor as a target for the neuronal actions of A $\beta$ (Jhamandas et al., 2011). Human amylin (h-Amylin (islet amyloid polypeptide) is a 37residue amyloidogenic peptide first isolated from pancreatic islets of Langerhans in patients with type 2 diabetes (Cooper et al., 1987). Human amylin acts via a G-protein-coupled receptor (amylin receptor) composed of the calcitonin receptor (CTR) and a receptor-associated membrane protein (RAMP) and demonstrates a profile of neurotoxicity that is strikingly similar to that of $\mathrm{A} \beta$ (Jhamandas et al., 2011). Thus, blockade of the amylin receptor with an antagonist (AC253) attenuates electrophysiological and neurotoxic actions of $\mathrm{A} \beta$ on human and rat fetal neurons and downregulation of the amylin receptor using siRNA blunts $\mathrm{A} \beta$ toxicity Further, we have shown it is the amylin-3 $(\mathrm{CTR}+\mathrm{RAMP} 3=\mathrm{AMY})$, but not AMY1 or AMY2, subtype of the amylin receptor that is most relevant for the activation of 
intracellular cAMP-dependent pathways and expression of $\mathrm{A} \beta$ and h-Amylin toxicity (Fu et al., 2012). Collectively, these observations raise the important question of whether the amylin receptor is also a target for the expression of deleterious effects of $\mathrm{A} \beta$ on synaptic plasticity and learning.

Herein, we sought to examine whether $A \beta$-induced reduction of LTP is also observed for h-Amylin, and if so, are such effects expressed via the amylin receptor. Furthermore, we investigated the basis for depressed LTP observed in APP overexpressing TgCRND8 mice with the notion that LTP in such mice could be restored (to levels observed in age-matched wild-type mice) by pharmacologically blocking the amylin receptor.

\section{Materials and Methods}

Mouse lines. For initial set of experiments examining the effects of $A \beta$ and h-Amylin on LTP, we used 2- to 3-month-old male or female C57BL/6 mice. For experiments investigating the role of the amylin receptor in LTP in mice overexpressing APP, we used transgenic (Tg) CRND8 mice (human APP695 transgene array incorporating Swedish K670M/N671L and Indiana V717F mutations superimposed upon a C57BL6/C3H genetic background that have been described previously to exhibit $\mathrm{A} \beta$ plaques and cognitive defects by 3 months of age (Chishti et al., 2001). Specifically we used 6- to 12-month-old TgCRND8 and age-matched, wild-type littermate (C57BL/6 background) male or female mice. All experiments were performed in compliance with the relevant laws and guidelines set by the Canadian Council for Animal Care and with the approval of the Human Research Ethics Board and Animal Care Use Committee (Health Sciences) at the University of Alberta.

Slice preparation and electrophysiology. Brains were quickly removed from mice following decapitation, placed in cold artificial CSF (aCSF) on a vibratome chamber and transverse sections cut through the hippocampus. The aCSF contained (in mM) $124 \mathrm{NaCl}, 3 \mathrm{KCl}, 2.4 \mathrm{CaCl}_{2}, 2 \mathrm{MgCl}_{2}$, $1.25 \mathrm{NaH}_{2} \mathrm{PO}_{4}, 26 \mathrm{NaHCO}_{3}$ and $10 \mathrm{D}$-glucose, and was equilibrated with $95 \% \mathrm{O}_{2}$ and $5 \% \mathrm{CO}_{2}$. Hippocampal slices (400 $\mu \mathrm{m}$ thick) were maintained in an aCSF-filled holding chamber at room temperature and transferred to the submerged recording chamber constantly perfused with aCSF $(2 \mathrm{ml} / \mathrm{min})$ at $30^{\circ} \mathrm{C}$. Field EPSP (fEPSP) was recorded with a metallic ( $\mathrm{Pt} / \mathrm{Ir}$ ) electrode (FHC, Inc.) from the stratum radiatum layer of cornu ammonis 1 region of the hippocampus (CA1) area, and the Schaffer collateral afferents were stimulated with $100 \mu$ s test pulses via a bipolar cluster electrode (FHC, Inc.) (Kimura and Ohno, 2009). To evaluate basal synaptic transmission, we applied different stimulation strengths (125-300 $\mu \mathrm{A}$ in steps of $25 \mu \mathrm{A}$ ) and plotted the amplitudes of presynaptic fiber volleys versus the corresponding fEPSP slopes to compare the slope of input-output $(I / O)$ curves of fEPSP. For LTP experiments, the stimulus strength was set to elicit $40-50 \%$ of the maximum fEPSP amplitude and test pulses delivered to Schaffer collaterals once every $30 \mathrm{~s}$. LTP was induced by a 3 theta burst stimulation (3-TBS) protocol (each burst consisted of 4 pulses at $100 \mathrm{~Hz}$ with a $200 \mathrm{~ms}$ interburst interval). Before 3-TBS or drug application, the responses were monitored for at least $10 \mathrm{~min}$ to ensure a stable baseline of fEPSP. To determine whether the magnitude of LTP differed significantly between groups, average responses during the last 20 min block of recordings ( $40-60$ min after TBS) were compared. To test paired-pulse facilitation, we measured the percentage increase in slope of the fEPSP relative to the first one with different interpulse intervals (20-500 ms).

Drugs and their application. Soluble oligomeric $\mathrm{A} \beta_{1-42}$, the reverse nonfunctional sequence peptide $\mathrm{A} \beta_{42-1}$, and h-Amylin were used in the present study and prepared as per previously published protocols (Stine et al., 2003; Jhamandas et al., 2011). $\mathrm{A} \beta_{1-42}$ and $\mathrm{A} \beta_{42-1}$ were purchased from rPeptide, and h-Amylin and AC253 were purchased from American Peptide. All drugs and chemicals were applied directly to the slice via bath perfusion, which allowed for a complete exchange of the perfusate in less than a minute and a half.

Immunohistochemistry. Following electrophysiological recordings, hippocampal brain slices from TgCRND8 and control wild-type mice were fixed with $4 \%$ paraformaldehyde for immunohistochemical analysis of $\mathrm{A} \beta$ plaque deposition (for details, see Jhamandas et al., 2011).
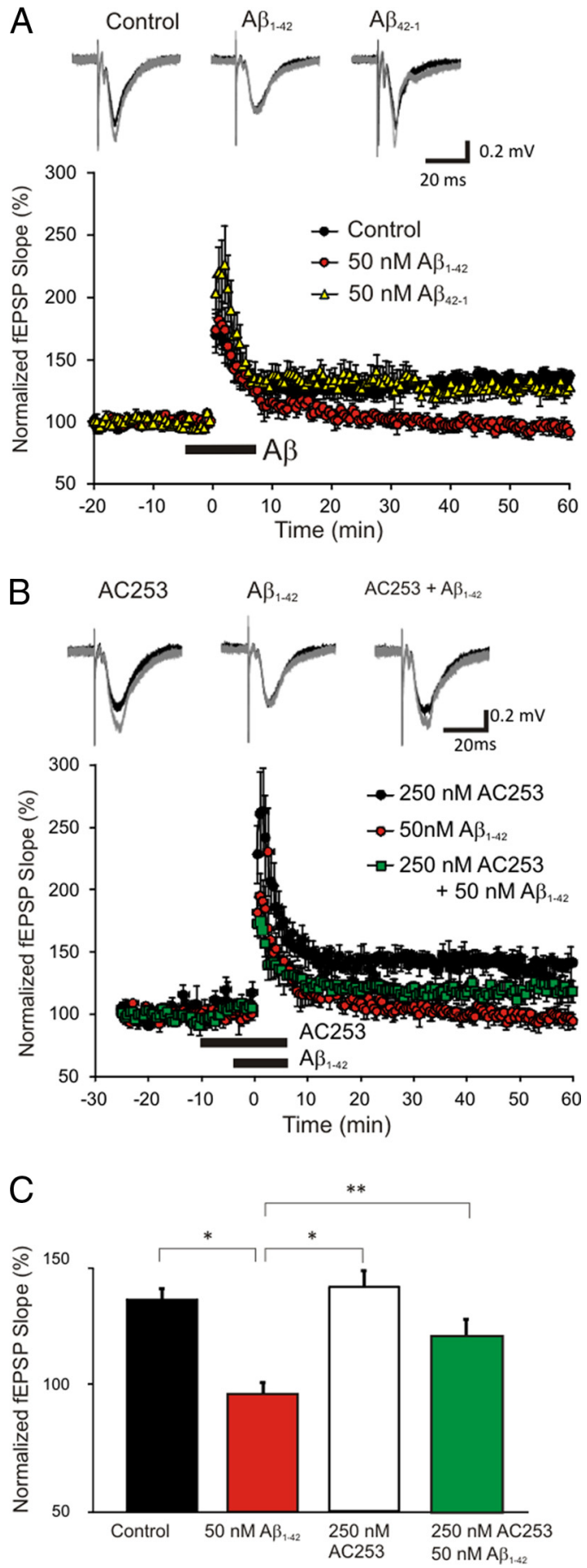

Figure 1. Amylin receptor antagonist $A C 253$ reverses $A \beta_{1-42}$-induced depression of hippocampal LTP. $A, A 50$ nm concentration of $A \beta_{1-42}$, but not $A \beta_{42-1}$, impaired LTP in hippocampal slices. LTP was induced by $3 \times$ TBS protocols at Schaffer collateral-CA1 synapses. $A \beta_{1-42}$ or $A \beta_{42-1}$ was perfused 5 min before and after $3 \times$ TBS. $B, A C 253$ (250 nM) reverses $A \beta_{1-42}$-induced depression of hippocampal LTP. AC253 was perfused 5 min before $50 \mathrm{~nm} \mathrm{~A} \beta_{1-42}$ application and LTP was induced by $3 \times$ TBS protocols in the presence of $A C 253$ and $A \beta_{42-1}$. Each point indicates the fEPSP slope normalized to the average baseline response over $10 \mathrm{~min}$ before drug is applied; the bars indicate onset and duration of application. All data are presented as mean \pm SEM. Traces are the average of fEPSPS recorded during baseline (black) and $40-60$ min after $3 \times$ TBS (gray). Calibration: 0.2 $\mathrm{mV}, 20 \mathrm{~ms}$ ( $n=4-6$ mice per group). $C$, The summary bar graphs show significant reductions in LTP as measured by $50 \mathrm{~nm} \mathrm{~A} \beta_{1-42}$ but not $50 \mathrm{~nm} \mathrm{~A} \beta_{1-42}$ with $250 \mathrm{~nm} \mathrm{AC253.}$ ${ }^{*} p<0.01$ for control vs $A \beta_{1-42}$ and $A C 253$ vs $A \beta_{42-1}$, and ${ }^{* *} p<0.05$ for $A \beta_{1-42}$ vs $A \beta_{1-42}$ with AC253; ANOVA Tukey's post hoc test. 
A

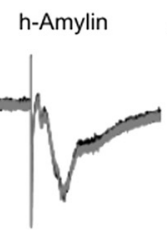

Ac253 + h-Amylin
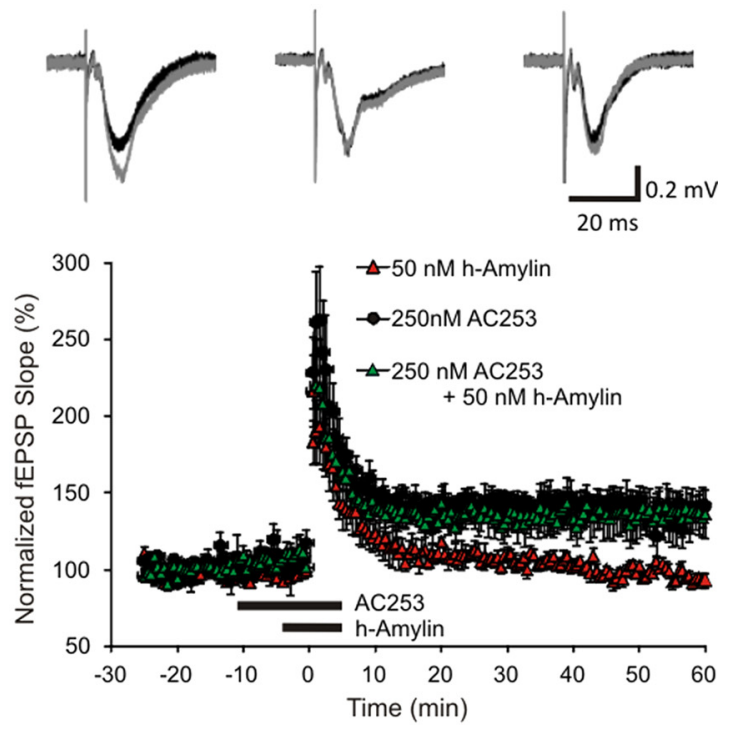

B

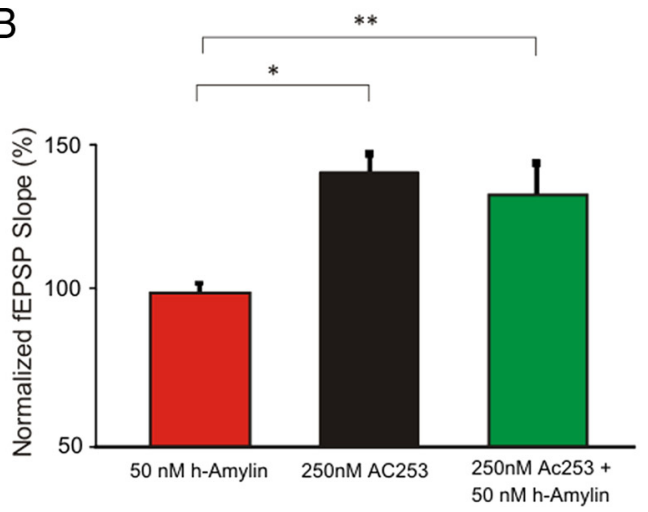

Figure 2. AC253 reverses h-Amylin-induced depression of hippocampal LTP. A, AC253 (250 nM) was perfused 5 min before $50 \mathrm{~nm}$ h-Amylin application and LTP was induced by $3 \times$ TBS protocols in the presence of AC253 and h-Amylin. Each point indicates the fEPSP slope normalized to the average baseline response over 10 min before drug is applied; the bars indicate onset and duration of application. All data are presented as mean \pm SEM. Traces are the average of fEPSPs recorded during baseline (black) and $40-60 \mathrm{~min}$ after $3 \times$ TBS (gray). Calibration: 0.2 $\mathrm{mV}, 20 \mathrm{~ms}$ ( $n=4-6$ mice per group). $\boldsymbol{B}$, The summary bar graphs show significant reductions in LTP with application of $50 \mathrm{~nm}$ h-Amylin, but not $50 \mathrm{~nm}$ h-Amylin with $250 \mathrm{~nm} \mathrm{AC253.}{ }^{*} \mathrm{p}<$ 0.01 for AC253 vs $h$-Amylin, and ${ }^{* *} p<0.05$ for h-Amylin vs $h$-Amylin with AC253; ANOVA Tukey's post hoc test).

Briefly, 25- $\mu \mathrm{m}$-thick hippocampal brain slices were sectioned, and freefloating sections were immunohistochemically stained with $6 \mathrm{E} 10$ mouse monoclonal antibody (Signet Laboratories) and visualized with Alexa Fluor 546 anti-mouse antibody (Invitrogen).

Statistics. Results were expressed as means \pm SE. Statistical analysis was performed using one-way ANOVA followed by post hoc Tukey's honestly significant difference (HSD) test (for multiple comparisons) or unpaired $t$ test (for pairwise comparisons).

\section{Results}

Effects of $A \beta_{1-42}$ on hippocampal LTP are expressed via the amylin receptor

Application of soluble oligomeric $\mathrm{A} \beta_{1-42}(50 \mathrm{nM})$ depressed LTP induced by a weak tetanization protocol at the CA1 region of wild-type mouse hippocampal slices. In contrast, using the same protocol of drug application (for $5 \mathrm{~min}$ before and following 3 -TBS), equimolar concentrations of the reverse peptide, $\mathrm{A} \beta_{42-1}$, did not cause any significant alteration in LTP (Fig. 1A). LTP was
A
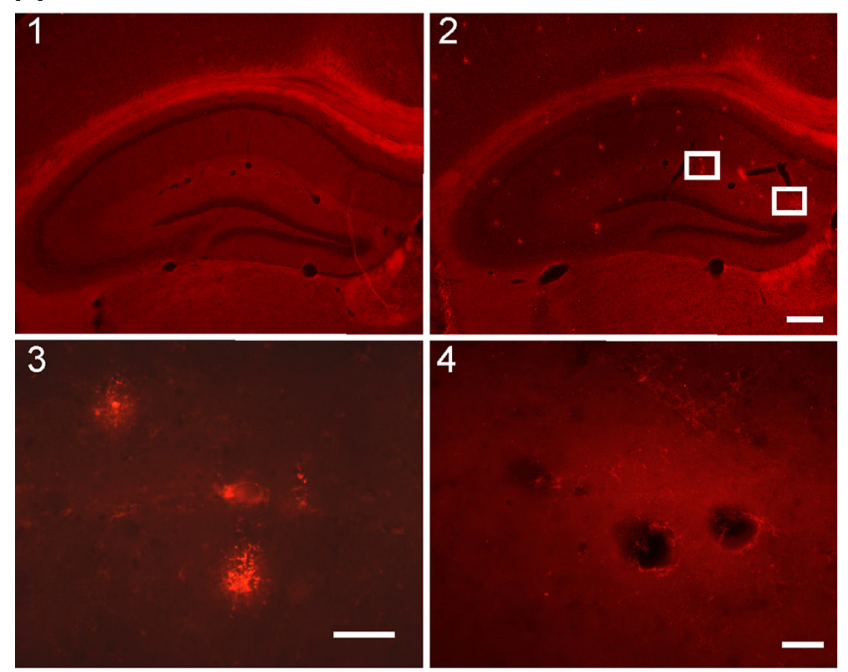

B
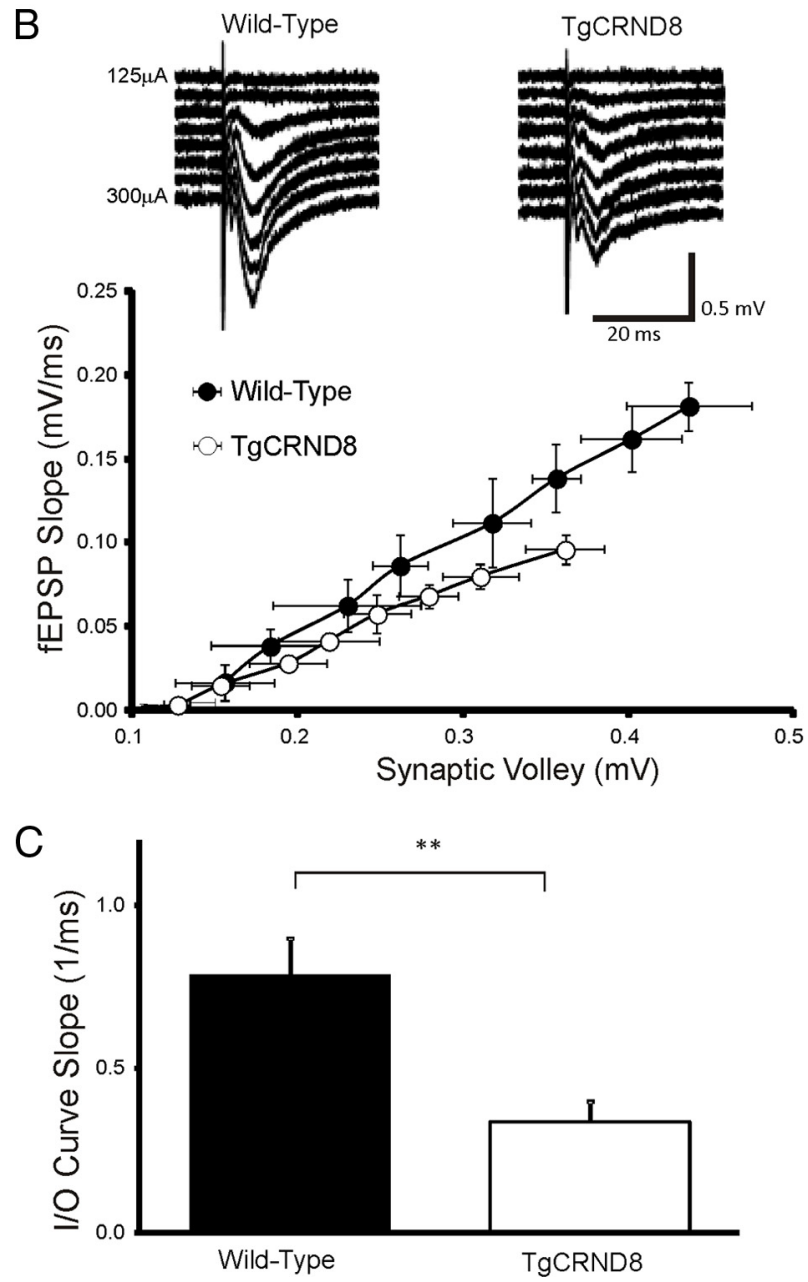

Figure 3. Impairments of basal synaptic transmission in hippocampal slices from TgCRND8 mice. $\boldsymbol{A}$, Immunohistochemical staining for amyloid within the hippocampus of wild-type (1) and TgCRND8 (2) mice. Boxed areas in $\mathbf{2}$ are shown at higher magnification in $\mathbf{3}$ and $\mathbf{4}$. In $\mathbf{3}$ amyloid plaques are visualized within the brain parenchyma, and in 4, amyloid deposits are observed within walls of blood vessels (seen as black holes). Scale bars: 1,2 (in 2), $200 \mu \mathrm{m} ; \mathbf{3}$, $4,20 \mu \mathrm{m} . B, I / 0$ curves relating the amplitude of the presynaptic fiber volley to the slope of fEPSP at various stimulus intensities (125-300 $\mu \mathrm{A}$ in $25 \mu \mathrm{A}$ increments). Traces are fEPSP responses at each stimulus intensity. $C$, The summary bar graph shows significant reductions in basal synaptic transmission as measured by the average slope of $/ / 0$ curves in TgCRND8 mice vs wild-type controls ( $n=7$ mice per each group, ${ }^{* *} p<0.05$; unpaired $t$ test). 
impaired with $50 \mathrm{nM} \mathrm{A} \beta_{1-42}(p<0.01$; unpaired $t$ test) but not $\mathrm{A} \beta_{42-1}(p=$ 0.3148 ; unpaired $t$ test) during the $40-60$ min period after induction (Fig. $1 A, C$ ). Application of $\mathrm{A} \beta_{1-42}$ in the period after LTP induction had no effect (data not shown). To determine whether $\mathrm{A} \beta_{1-42-}$ induced reduction in LTP is expressed amylin receptors, we used AC253 (LGRL SQELHRLQTYPRTNTGSNTY), a polypeptide that is a potent amylin receptor antagonist. We applied $250 \mathrm{~nm}$ AC253 continuously for $5 \mathrm{~min}$ before exposure of the hippocampal slices to $50 \mathrm{nM} \mathrm{A} \beta_{1-42}$ and for 5 min after LTP induction. The concentration of AC253 used was selected based on prior studies that examined the ability of this antagonist to block $\mathrm{h}$-Amylin and $\mathrm{A} \beta$ in rat and human fetal neurons and HEK293 cells transfected with subtypes of amylin receptors (Jhamandas and MacTavish, 2004; Jhamandas et al., 2011; Fu et al., 2012). AC253, applied alone did not affect control LTP (Fig. $1 B, C ; p=0.9189$, Tukey's HSD test), However, application of AC253 resulted in a significant restoration of hippocampal LTP observed following exposure of the brain slices $A \beta_{1-42}$ (Fig. $1 B, C ; p<0.05$, Tukey's HSD test).

\section{Human amylin induces depression of hippocampal LTP}

We further investigated whether application of h-Amylin also causes the basal depression of hippocampal LTP induced by 3-TBS protocol in a manner similar to that induced by $\mathrm{A} \beta_{1-42}$. Human amylin (50 nM) application also resulted in impaired hippocampal LTP (Fig. 2A; $p<$ 0.01 , unpaired $t$ test), which could be reversed with preapplication of AC253 (250 nm; Fig. 2A, B; $p<0.05$, Tukey's HSD test).

\section{Hippocampal synaptic disruption in TgCRND8 mice}

To identify a potential role for the amylin receptor in an animal model where cognitive and memory deficits are attributable to presence of significant brain levels of $\mathrm{A} \beta$, we examined hippocampal LTP in TgCRND8 mice that overexpress mutant human APP695. TgCRND8 mice at 6 months and older demonstrate marked amyloid deposition in the hippocampus and cortex than age-matched wild-type littermate controls (Fig. 3A). In hippocampal slices from 6- to 12-month-old TgCRND8, $I / O$ curves of fEPSPs in response to different stimulation strengths were significantly different from those of wild-type controls (Fig. $3 B$ ). Consequently, basal synaptic transmission as assessed by the average slope of $I / O$ curves was reduced in TgCRND8 mice ( $p=$ $0.0063<0.01$; unpaired $t$ test; Fig. $3 C$ ). However, we were able to evoke LTP at hippocampal Schaffer collateral-CA1 synapses of both wild-type and hemizygous transgenic mice as demonstrated in Figure 4B. LTP induced by 3-TBS was significantly depressed during 40-60 min after its induction in TgCRND8 mice compared with wild-type age-matched controls ( $p<0.05$; unpaired $t$ test). Therefore, basal excitatory synaptic transmission (as assessed by $I / O$

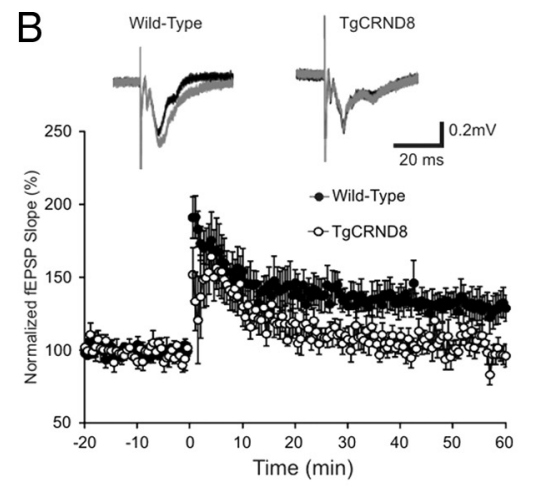

D

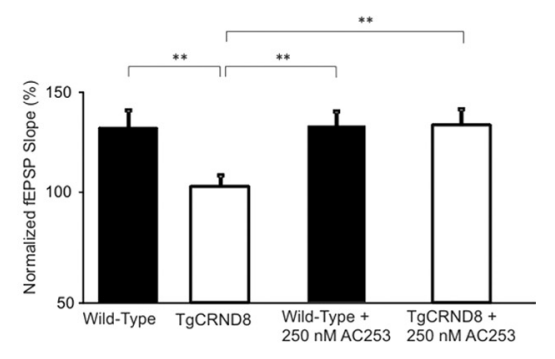

relationships) and LTP at hippocampal CA1 are reduced in TgCRND8 mice, as reported in other AD transgenic mouse models (for reviews see Rowan et al., 2003, Wilcox et al., 2011).

\section{A $\beta$ depression of hippocampal LTP in TgCRND8 mice is amylin receptor dependent}

First, we tested the effects of AC253 on paired-pulse facilitation which represents a short-term form of synaptic plasticity reflecting presynaptic transmitter release probability. Paired-pulse facilitation was indistinguishable between TgCRND mice and controls at $>6$ months of age (Fig. $4 A$ ). We next examined whether LTP at hippocampal Schaffer collateral-CA1 synapses of TgCRND8 mice is dependent on the amylin receptor. Preapplication of AC253 (250 nM) to hippocampal slices for 5 min before and after 3-TBS, did not affect LTP during 40-60 min after induction in wild-type mice ( $p=0.9999$, Tukey's HSD test, Fig. $4 B)$. However, basal depression of LTP in TgCRND8 is restored by application of $250 \mathrm{~nm} \mathrm{AC253} \mathrm{(} p=<0.05$, Tukey's HSD test) to comparable levels that are observed in age-matched wild-type littermate mice ( $p=0.9997$, Tukey's HSD test) (Fig. 4C,D). Furthermore, in TgCRND mice, AC253 applied without TBS had no effect on fEPSPs (data not shown). 


\section{Discussion}

In this study we report that the amyloidogenic protein h-Amylin, like soluble oligomeric $A \beta$, inhibits hippocampal LTP and both the h-Amylin- and A $\beta$-induced impairment of LTP is blocked by the amylin receptor antagonist, AC253. Further, in the presence of AC253, depression of LTP in transgenic mice that overexpress APP (Tg CRND8) reported by others (Bellucci et al., 2006; Arrieta-Cruz et al., 2010), and confirmed by us, is reversed to levels seen in wild-type, age-matched control littermate mice. The notion that h-Amylin is capable of disrupting synaptic plasticity seems at first inconsistent with the multiple basic homeostatic regulatory functions ascribed to this endogenous peptide. However, available data indicate that amylin effects may be concentration dependent. The usual plasma concentration for $\mathrm{h}$-Amylin is in the low picomolar range, even following stimuli that promote a release of the peptide in response to glucose load (Butler et al., 1990). At these concentrations, which regulate feeding and energy metabolism, the peptide seems nontoxic, and it is only at higher concentrations (nanomolar to micromolar range) that h-Amylin seems to exert its toxic effects (Fu et al., 2012).

Multiple receptors have been postulated as candidates for the expression of biological effects of $A \beta$ in in vitro and in vivo models that recapitulate, in part, features of $\mathrm{AD}$ pathology (Patel and Jhamandas, 2012). Of these, we have focused on the amylin receptor, which comprises of a combination of CTR and RAMP, serves as a target receptor for human amylin, and has a widespread CNS distribution including within the rodent and primate hippocampus (Sexton et al., 1994; Paxinos et al., 2004). Moreover, discrete peptide sequences of $\mathrm{A} \beta$ and amylin have been identified as interfaces for self- and cross-interaction between the two peptides (Andreetto et al., 2010). We have identified that the direct effects of $\mathrm{A} \beta$ on human and rat fetal neurons are expressed via the amylin receptor, and furthermore, data from HEK293 cells transfected with subtypes of amylin receptors suggests that it is the AMY3 rather than AMY1 (CTR + RAMP1) or AMY2 (CTR + RAMP2) receptor that is the specific target for $A \beta$ (Jhamandas and MacTavish, 2004; Jhamandas et al., 2011; Fu et al., 2012). The present data suggest that in an in vitro paradigm of synaptic plasticity (LTP), the depressant effects of low nanomolar concentrations of A $\beta$ are also expressed via the amylin receptor.

TgCRND8 mice encode a double mutant form of APP695 (KM670/671NL+V717F) under the control of the PrP gene promoter and recapitulate many of the essential features of $\mathrm{AD}$ pathology in an accelerated fashion (Chishti et al., 2001). Histological deposition of $\mathrm{A} \beta$ in plaque form is evident in $100 \%$ of animals by 3 months of age and dystrophic neuritic changes at hippocampal synapses are present at 5 months of age. These neuropathological changes correlate with cognitive and behavioral impediment that are observed as early as 3 months of age. Our study demonstrates that electrophysiological markers of hippocampal synaptic dysfunction, as assessed by reductions in both basal synaptic transmission (I/O curves) and LTP, are present in all TgCRND8 mice by 6 months of age compared with agematched, wild-type littermates in whom no synaptic impairment was identified. Short-lived presynaptic plasticity as measured by paired pulse facilitation was normal in TgCRND8 and wild-type mice as reported for other mouse models (Chapman et al., 1999; Kimura and Ohno, 2009). Treatment of hippocampal brain slices with AC253 resulted in restoration of LTP recorded from TgCRND8 mice to levels that are observed in wild-type controls. However, in TgCRND8 mice, AC253 had no effect on fEPSPs recorded during application of the drug either before LTP induc- tion or in the absence of TBS. We and others have shown that total hippocampal $\mathrm{A} \beta$ levels (in soluble oligomeric and plaque form) in TgCRND8 mice $>6$ months of age are markedly elevated compared with wild-type littermates (Chishti et al., 2001; Jhamandas et al., 2011). We suggest that the increase in ambient $\mathrm{A} \beta$ levels in TgCRND8 mice is responsible for depression of LTP that is observed in these animals as they get older and that blockade of the amylin receptor, which we have shown to serve as a putative target receptor for $\mathrm{A} \beta$, causes an improvement in LTP. Interestingly, we have also observed that the age-dependent and region-specific (cortex, hippocampus and septum) increases in the amylin receptor (CTR and RAMP3) and A $\beta$ in TgCRND8 mice are also apparent in cortex and hippocampus in postmortem brain tissue from AD patients compared with age-matched controls (our unpublished observations).

The nature and mechanisms of the soluble oligomeric $\mathrm{A} \beta$ interaction with the amylin receptor, specifically the AMY3 moiety comprising CTR and RAMP3 (Fu et al., 2012) deserve comment. We have previously shown that the locus of such a ligandreceptor interplay is at the level of the postsynaptic membrane where $\mathrm{A} \beta$, through the amylin receptor, modulates activity of a suite of ionic conductances, mostly potassium channels, that results in increased neuronal excitability, elevations in intracellular calcium levels and activation of cAMP along with other downstream signal transduction mediators (Jhamandas and MacTavish, 2004; Jhamandas et al., 2011; Fu et al., 2012). A $\beta$ is also capable of synaptic effects by depressing excitatory synaptic transmission in rat brain slices, possibly via metabotropic glutamate receptors (Chin et al., 2007). These events play out on a relatively short time scale (milliseconds to minutes) but have the potential to disrupt intracellular homeostasis and synaptic plasticity. Longer exposures to soluble oligomeric $A \beta$ has been shown in many in vitro paradigms to result in cell death via apoptotic and non-apoptotic mechanisms (Selkoe, 2008; Jhamandas et al., 2011). Thus, application of amylin receptor antagonists or siRNA downregulation of the amylin receptor blunts both the early and late events attributable to the soluble oligomeric $\mathrm{A} \beta$ species. The present study provides first preclinical evidence for restoration of $A \beta$-induced impairment of synaptic plasticity using blockade of the amylin receptor and suggest that antagonists for this receptor, originally developed for the treatment of diabetes mellitus, may offer promising therapeutic option for AD.

\section{References}

Andreetto E, Yan LM, Tatarek-Nossol M, Velkova A, Frank R, Kapurniotu A (2010) Identification of hot regions of the A $\beta$-IAPP interaction interface as high-affinity binding sites in both cross- and self-association. Angew Chem Int Ed Engl 49:3081-3085. CrossRef Medline

Arrieta-Cruz I, Wang J, Pavlides C, Pasinetti GM (2010) Carvedilol reestablishes long-term potentiation in a mouse model of Alzheimer's disease. J Alzheimers Dis 21:649-654. Medline

Bellucci A, Luccarini I, Scali C, Prosperi C, Giovannini MG, Pepeu G, Casamenti F (2006) Cholinergic dysfunction, neuronal damage and axonal loss in TgCRND8 mice. Neurobiol Dis 23:260-272. CrossRef Medline

Butler PC, Chou J, Carter WB, Wang YN, Bu BH, Chang D, Chang JK, Rizza RA (1990) Effects of meal ingestion on plasma amylin concentration in NIDDM and nondiabetic humans. Diabetes 39:752-756. CrossRef Medline

Chapman PF, White GL, Jones MW, Cooper-Blacketer D, Marshall VJ, Irizarry M, Younkin L, Good MA, Bliss TV, Hyman BT, Younkin SG, Hsiao KK (1999) Impaired synaptic plasticity and learning in aged amyloid precursor protein transgenic mice. Nat Neurosci 2:271-276. CrossRef Medline

Chin JH, Ma L, MacTavish D, Jhamandas JH (2007) Amyloid $\beta$ protein modulates glutamate-mediated neurotransmission in the rat basal forebrain: Involvement of presynaptic neuronal nicotinic acetylcholine and 
metabotropic glutamate receptors. J Neurosci 27:9262-9269. CrossRef Medline

Chishti MA, Yang DS, Janus C, Phinney AL, Horne P, Pearson J, Strome R, Zuker N, Loukides J, French J, Turner S, Lozza G, Grilli M, Kunicki S, Morissette C, Paquette J, Gervais F, Bergeron C, Fraser PE, Carlson GA, et al. (2001) Early-onset amyloid deposition and cognitive deficits in transgenic mice expressing a double mutant form of amyloid precursor protein. J Biol Chem 276:21562-21570. CrossRef Medline

Cooper GJ, Willis AC, Clark A, Turner RC, Sim RB, Reid KB (1987) Purification and characterization of a peptide from amyloid-rich pancreases of type 2 diabetic patients. Proc Natl Acad Sci U S A 84:8628-8632. CrossRef Medline

Fu W, Ruangkittisakul A, MacTavish D, Shi JY, Ballanyi K, Jhamandas JH (2012) Amyloid beta (A $\beta$ ) peptide directly activates Amylin-3 receptor subtype by triggering multiple intracellular signalling pathways. J Biol Chem 287:18820-18830. CrossRef Medline

Huang Y, Mucke L (2012) Alzheimer mechanisms and therapeutic strategies. Cell 148:1204-1222. CrossRef Medline

Jhamandas JH, MacTavish D (2004) Antagonist of the amylin receptor blocks $\beta$-amyloid toxicity in rat cholinergic basal forebrain neurons. J Neurosci 24:5579-5584. CrossRef Medline

Jhamandas JH, Li Z, Westaway D, Yang J, Jassar S, MacTavish D (2011) Actions of $\beta$-amyloid protein on human neurons are expressed through the amylin receptor. Am J Pathol 178:140-149. CrossRef Medline

Kimura R, Ohno M (2009) Impairments in remote memory stabilization precede hippocampal synaptic and cognitive failures in 5XFAD Alzheimer mouse model. Neurobiol Dis 33:229-235. CrossRef Medline

Klyubin I, Walsh DM, Lemere CA, Cullen WK, Shankar GM, Betts V, Spooner ET, Jiang L, Anwyl R, Selkoe DJ, Rowan MJ (2005) Amyloid beta protein immunotherapy neutralizes Abeta oligomers that disrupt synaptic plasticity in vivo. Nat Med 11:556-561. CrossRef Medline

Patel AN, Jhamandas JH (2012) Neuronal receptors as targets for the action of amyloid-beta protein $(\mathrm{A} \beta$ ) in the brain. Expert Rev Mol Med 14:1-19.

Paxinos G, Chai SY, Christopoulos G, Huang XF, Toga AW, Wang HQ, Sexton PM (2004) In vitro autoradiographic localization of calcitonin and amylin binding sites in monkey brain. J Chem Neuroanat 27:217-236. CrossRef Medline

Rowan MJ, Klyubin I, Cullen WK, Anwyl R (2003) Synaptic plasticity in animal models of early Alzheimer's disease. Philos Trans R Soc Lond B 358:821-828. CrossRef

Selkoe DJ (2008) Soluble oligomers of the amyloid beta-protein impair synaptic plasticity and behavior. Behav Brain Res 92:106-113.

Sexton PM, Paxinos G, Kenney MA, Wookey PJ, Beaumont K (1994) In vitro autoradiographic localization of amylin binding sites in rat brain. Neuroscience 62:553-567. CrossRef Medline

Stine WB Jr, Dahlgren KN, Krafft GA, LaDu MJ (2003) In vitro characterization of conditions for amyloid-beta peptide oligomerization and fibrillogenesis. J Biol Chem 278:11612-11622. CrossRef Medline

Townsend M, Qu Y, Gray A, Wu Z, Seto T, Hutton M, Shearman MS, Middleton RE (2010) Oral treatment with a $\gamma$-secretase inhibitor improves long-term potentiation in a mouse model of Alzheimer's disease. J Pharmacol Exp Ther 333:110-119. CrossRef Medline

Walsh DM, Klyubin I, Fadeeva JV, Cullen WK, Anwyl R, Wolfe MS, Rowan MJ, Selkoe DJ (2002) Naturally secreted oligomers of amyloid beta protein potently inhibit hippocampal long-term potentiation in vivo. Nature 416:535-539. CrossRef Medline

Wilcox KC, Lacor PN, Pitt J, Klein WL (2011) A $\beta$ oligomer-induced synapse degeneration in Alzheimer's disease. Cell Mol Neurobiol 31:939_ 948. CrossRef Medline 